\title{
HAPPINESS AS FATE, SENSE, MEANING, AND ALLOTMENT
}

In Happiness And Contemporary Society : Conference Proceedings Volume (Lviv, March, 20-21, 2021). Lviv: SPOLOM, 2021. P. 148-152. https://doi.org/10.31108/7.2021.33

ISBN 978-966-919-697-2

\section{ЩАСТЯ ЯК СУДЬБА, СЕНС, СМИСЛ I доля}

// Щастя та сучасне суспільство : збірник матеріалів міжнародної наукової конференції (Львів, 20-21 березня 2021 р.). - Львів : СПОЛОМ, 2021. С. 148-152. https://doi.org/10.31108/7.2021.33

ISBN 978-966-919-697-2 


\section{KARAS Anatoliy \\ Doctor of Sciences in Philosophy, Full Professor, Head of the Department of Philosophy, Ivan Franko National University of Lviv (Lviv, Ukraine)}

\section{HAPPINESS AS FATE, SENSE, MEANING, AND ALLOTMENT}

Happiness is when what you think, what you say and what you do are in harmony" Gandhi

Happiness, as a semiotic object, is a multifaceted and shimmering nuance of the phenomenon of personal self-fulfillment and social transformation. Human is born neither free nor happy. However, she is born with the gift of life, although "abandoned" in the contingent destiny, but able to overcome it and gratefully pass it on to others. From this perspective, we have good reason to expect that "human is born for happiness." She can become happy by understanding and overcoming her natural limitations on the path to inner freedom and a positive presence in another person's life. Happiness means discovering our creative possibilities to become ourselves, receiving the joy of the fullness of life.

\section{КАРАСЬ Анатолій \\ доктор філософських наук, професор, завідувач кафедри філософії Львівський начіональний університет імені І.Франка (Львів, Украӥна)}

\section{ЩАСТЯ ЯК СУДЬБА, СЕНС, СМИСЛ І ДОЛЯ}

Чи може щастя бути благом для людини і водночас - благом для суспільства? Іншими словами, чи існує зв'язок між щастям людини і суспільним добробутом? Відповіді на ці питання залежать від філософсько-етичних поглядів і $\epsilon$ неоднозначними. Проте це не применшує вагомості феномену щастя в житті людини і в суспільному розвитку.

За період після Другої світової війни суспільства стали багатшими, а люди створюють і споживають дедалі більше речей і цінностей. Але чи зменшилась кількість проблем, які насідають на сучасну людину і чи стала вона щасливішою? Одним із кричущих викликів сьогодення $\epsilon$ разюча відмінність між багатими i бідними людьми і країнами. Тож чи знайдемо ми достатні підстави вважати усіх багатих - щасливими, а всіх бідних нещасними? Відповідь на це запитання майже очевидна - підстав для такого судження не достатньо. А коли так, чи не означає це, що суть щастя $\epsilon$ винятково релятивною й позбавленою несуперечливого раціонального обгрунтування?

У цьому тексті я пропонуватиму проаналізувати феномен щастя як комунікативно-конвенційний семіотичний об'єкт, що існує на підставі стійких референційних відношень довкола низки ключових чинників людського життя. До таких чинників пропоную віднести: життя і смерть, його індивідуалізацію $\mathrm{i}$ 
персоналізацію, тілесність і ментальність, судьбу і долю, задоволення і радість, необхідність і відповідальність, волю і свободу, сенс і смисл, прагнення i присутність.

Покликаючись на Ч. С. Пірса, знаємо, що об'єктами нашого розуму і сприйняття є тільки те, що позначене знаками. Серед об'єктів, які існують в розумі, $\epsilon$ такі, що репрезентують реальні фізичні феномени, i такі, що репрезентують ментальні феномени, які існують поза фізичним статусом. Третій клас об'єктів має мішану природу - вона поєднує в собі референцію з фізичними, віртуальними і прагматичними (аксіологічними) ознаками. До цього класу об'єктів належить переважна більшість феноменів соціального життя: справедливість, добробут, рівність, любов, солідарність, довіра, щастя тощо. Всі класи об'єктів існують, тобто всі вони належать до буття. Відтак, семіотичний об'єкт - це конвенційно впорядкована структура елементів, що репрезентує певну сукупність референційних відношень між середовищем і ментальністю (розумом). У розумі референційні відношення прочитуються як семантичні 3 різним ступенем значущості.

Парадоксально, але навіть на війні, де над життям панують детерміністичні умови, також є місце для людського щастя - ним називаємо можливість вижити. Якщо ж вдається вижити без каліцтва - це вже подвійне щастя. Але й тут не все так просто. Адже цінність людського життя вимірюється в його протиставленні зі смертю та іiі загрозами. Один із семантичних варіантів щастя - це витлумачити цінність життя з погляду стоїчного героїзму або самопожертви заради інших.

Загалом, міра нашого людського щастя визначається умовами, які складаються під впливом взаємодії детермінізму i свободи. Життя, що поглинається детерміністичною ситуацією, важко назвати щасливим. Не можемо означати поняттям «щастя» те, що не залежить від людини. Водночас очевидно, що не людина породжує життя, але життя, як глобальний чи навіть космічний феномен, породжує велику багатоманітність життєвих видів та індивідів. 3 цього випливає, що життя саме по собі у своїй іманентній природі споріднене з певним детермінізмом, або тим, що у філософії позначається як «воля-до-життя» в іiі тілесно-ментальному (чи тілесно-духовному) існуванні.

Людина приходить у світ як індивідуалізоване буття з тілесно визначеними параметрами існування: кожен 3 нас народжується у конкретному часопросторі, 3 певними генетичними, расовими, етнічними й іншими спадковими ознаками. У цьому судьба людини, але не в судьбі iï покликання. Людям суджено народжуватись, скажімо, у Львові, Парижі, Катманду, Каїрі, Лондоні, Пекіні, у віддаленому гірському хуторі чи навіть у Москві. Не ми визначали дати свого народження: кому прийти ще на зорі людства, кому в часи чуми або холери, кому для Голокосту, кому для Голодомору, а кому - для «загірного щастя», як Народному Малахію з містечка Вчорашнього у драмі М. Куліша.

Можна було б вважати темпоральні й генетичні параметри з'яви людини на світ цілком випадковими, якби не йшлося власне про життя у його еволюційному проявленні. Тому точніше говорити про «контингентність» у сенсі «прив'язування» індивідуального існування людини до певного життєвого світу, соціокультурного часопростору, або ж у термінах семіотики - «умвельту». Контингентність $є$ тим, що називаємо словом «судьба» для увиразнення індивідуального генетично-тілесного, темпорального й чуттєвого існування людини. 
На рівні «судьби» особа розгортає і формує свою чуттєво-емоційну сферу довкола дихотомічного сприйняття світу за принципом «свій» - «чужий», «задоволення» - «незадоволення». Судьба людини дається 3 сенсорикою, обумовленою специфікою і межами «Умвельту». Ми «насичуємо» наше існування сенсами, що сформовані під впливом культури, традицій і звичного у плані безпеки реагування на ситуації. Тобто сенси обумовлюються культурним середовищем і проявляються певним варіативним типом реагування і сприйняття дійсності в дихотомії задоволення-незадоволення чи безпеки-небезпеки. Проблеми сенсосприйняття виникають 3 того, що у прагненні чуттєвих задоволень людина, на відміну від тварини, може легко ставати ненаситною і пересиченою, втрачаючи почуття міри.

Коли людина одержує те, чого вона хоче, вона одержує також задоволення чи насолоду. Проте 3 досвіду довідуємося, що бути задоволеним - далеко не завжди означає перебувати в стані радості. Хоча без задоволення немає радості, але між ними немає рівності. Згадаймо, вже Демокріт писав про те, що радість належить до субстанційного стану існування, тоді як задоволення - до атрибутивного. Тобто на відміну від сенсо-сенсорного й афективного характеру задоволення, радість стосується його семантично-смислового рівня.

Життя, яке насичене звичайним задоволенням повсякденних бажань і потреб, цілком можна вважати відносно щасливим - адже людина здорова і не позбавлена утіх. Це також щастя - бути вільним від голоду, холоду і небезпеки. Ситість позбавляє від детерміністичного тиску голоду, обумовленого тілесною природою. Ситість, але не пересиченість. Міра, а не надмірність - зупиняє тілесну фатальність судьби.

Проте судьба - це не просто «присуд», суджений людині в ії тілесноафективному існуванні. Це також дарунок життя як такого, що призначене для його «передарування», для його продовження в іншому і через іншого. Життя, як судьба, належить конкретній людині, але «життя» як таке - перевершує контингентність конкретно-тілесного існування. Його суть є трансцендентною, вона - у здатності його поширення, у подоланні видових, часопросторових $\mathrm{i}$, ймовірно, навіть біологічних меж. Людина, свідомо і несвідомо, долає життєві перешкоди, перебуваючи на шляху до власної долі - у чомусь щасливої і в чомусь нещасливої.

Почуймо Івана Франка:

Отсе, сини мої, мій рідний край - для вас!

Любіть, любіть його!

Судьби сповниться доля

I швидко власть чужа

пропаде з сего поля!

Найважливішими для людей $€$ стосунки, обумовлені тією частиною людського життя, яку давні греки нарекли поняттям «тимосу». Стосуються вони нашої потреби в іншій людині - у людському прагненні бути бажаним для інших.

Наш давньогрецький приятель Платон запровадив поняття «тимос» у трактаті про «Державу». Ним означується, поряд 3 «жаданнями» і «розумом», сердечне й афективне прагнення людини до визнання й самовираження гідності. Тимос стосується тієї ментально-тілесної сфери життя, яка проявляється у людських прагненнях, намірах, мотивах і ними викликаних діях. На споді тимосу 
перебуває енергія, названа греками еросом. Тому зміст тимосу $є$ вкрай суперечливим щодо сенсів задоволення і смислових варіантів його здійснення. Пристрасне й добровільне прагнення до обраної мети звільняє людину навіть від страху смерті. У цьому полягає вкрай важливий смисловий наголос щодо грецького розуміння свободи.

Йдеться про семантику свободи в ї̈ референиії до феноменів внутрішнього стану людини, на відміну від референції до зовнішніх речей $i$ станів, яку семантично маркуємо словом «воля» і сприймаємо в смисловому контексті звільнення, наприклад, від кайданів, рабства, в’язниці, а також від голоду, холоду й небезпеки. Виглядає на те, що саме цей, другий, смисловий контекст розуміння свободи як волі веде до гедоністичного тлумачення щастя через семантичну редукцію життя до його тілесного й емпіричного сенсоствердження.

Можна доповнити це міркування прикладами 3 огляду на сучасну проблематику свободи-як-волі в тому плані, в якому їі розуміння може редукуватися до сенсів комунікативно-дискурсивної практики патерналізмуклієнтизму. У цьому соціально-культурному контексті сенс задоволення репродукується позарефлексивним прагненням до визнання пільг і привілеїв. Це стосується такого суб'єктивного стану людини, в якому перебування під «сеньйоральною» опікою влади дозволяє гедоністично втішатися «вольностями» вже тільки тому, що вони не належать усім. Цей варіант прагнення греки визначали як мегалотимію, тобто прагнення до визнання винятковості, на відміну від ізотимії - прагнення до визнання рівності.

Якщо мегалотимія притаманна людині від природи як прояв іiі судьби і для неї властиві детерміністичні еволютивні спонуки, то ізотимія притаманна доброчесним громадянам, або ж людям 3 намірами і мотивами, що запліднюються розумом в його прагненні до знань, внутрішньої свободи і правди. Маштабування внутрішньої свободи визначалося греками через діяльне звільнення від судьби, що несе «фатальний», або кармічний «гюбріс», яким вони позначили порочну людську здатність до задоволення через домінування, приниження, образу і знущання над іншими. Це внутрішнє звільнення як суб'єктивне преображення мотивується розумом і знаннями, що, своєю чергою, осягаються посередництвом комунікації між людьми, які налаштовані шанувати свободу думки.

Полілогічне й раціональне осмислення спільних проблем народжує нові смисли, якими запліднюються прагнення, мотиви і дії. У цей спосіб смисли втручаються у людські судьби, персоналізуючи і перетворюючи їх в тому чи іншому напрямку, правда, не завжди позитивному. Ситуація преображення стосується переналаштування чуттєво-емоційного сенсосприймання, що відбувається під впливом семантики i прагматики, викликаних новими комунікативними смислами.

Реконструювання емоційної сфери викликає оновлення i розширення екзистенційного горизонту щодо перебігу задоволення-незадоволення: до нього потрапляють нові прагнення, нові смисли і нові потреби. Подібним чином, наприклад, до сенсосприймання колишніх язичників проникає смисл Нового Заповіту чи Корану й вони добровільно стають християнами чи мусульманами. Подібне відбувається 3 наверненням людини до ідей комунізму, запліднених марксистським осмисленням історичного процесу i соціальних відносин. Відмінності між релігійним та атеїстичним марксистським характером навернення обумовлюються різними прагненнями: (а) ідеєю внутрішнього спасіння від 
гріховності через покору Богові, та (б) ідеєю зовнішнього визволення від бідності й несправедливості через відкидання цінності Бога. Й хоча міра щастя і нещастя у кожного своя, шлях до нього прокладаємо самостійно, долаючи екзистенційні перешкоди під впливом тих чи інших смислових настанов, запакованих в наративах, дискурсах і культурних практиках. Відтак, трапляються ситуації, в яких прагнення до задоволення може набувати симулятивного характеру, а щастя носитиме примарний і характер симулякра.

Під впливом комунікативно-дискурсивної практики, що заснована на розумі, знаннях і свідомості, відбувається процес перетворення істоти, яка покладається на грубу силу, на персоналізовану в людяності особу. Зовнішнє соціально-культурне перетворення суспільних структур $€$ водночас внутрішнім суб'єктивним преображенням психологічних структур людини щодо іiі здатності до самоконтрольованої, розважливої поведінки. Це двобічний процес осягнення щастя через формування людяності: (а) подолання гюбріс через його усвідомлення і прагнення ізотимії, та (б) конструювання чуттєво-емоційного переживання, обумовленого новим смислом свободи (як внутрішнього самозвільнення), орієнтованим на врахування потреб інших.

У контексті спілкування і комунікації, запліднених знаннями і смислом свободи, коли стан задоволення позбавляється суто тілесної егоїстичної референції, приходить емоційне усвідомлення радості в іiї внутрішній спорідненості зі станом щастя. Очевидно, радість завжди є сигналом зі сфери поезису і мистецтва, творення і преображення. Поезис (poiesis, лоínбı)) у греків позначав стан перетворення і розмноження, ядром якого є виникнення нового, або оновлення. Наприклад, таким є прагнення смертних до безсмертя, про яке оповідає Діотима у «Симпозіумі» Платона. Смисл поезису також криється в його здатності до подолання нігілізму.

Мовою радості є прагнення до визнання через співчуття і любов, вона промовляє емпатичним покликом підтримки життя, починаючи 3 продовження роду. Не випадково ми найбільше визнаємо i шануємо тих, чиє життя продовжується у створених ними речах, предметах і товариських стосунках, які приносять радість іншим. У таких корисних для інших «речах» і «стосунках» здійснюється наша присутність в житті. Тобто, існування набуває позитивного значення.

Проте наше визнання людини щасливою, не завжди збігається з ії̈ власним відчуттям щастя. Цей парадокс пізнаємо зокрема 3 прикладів Сократа i Тараса Шевченка: те, що добре для громади - не завжди добре для ії подвижників. Чи ж були вони щасливими? Гадаю, що рівно настільки, наскільки перебували в радості творчого піднесення.

Таким чином, щастя, як семіотичний об'єкт, є багатогранним і мерехтливим нюансами феноменом персонального самоздійснення і суспільного перетворення. Людина не народжується ні вільною, ні щасливою. Проте вона народжується 3 дарунком життя, хоча й «закинутого» в контингентній судьбі, але здатного до іiі подолання і вдячного передарування. 3 цієї перспективи маємо достатні підстави очікувати, що «людина народжена для щастя». Вона може ставати щасливою, осмислюючи і долаючи свої природні обмеження на шляху до внутрішньої свободи й позитивної присутності в житті іншої людини. Щастя означає відкривати наші творчі можливості, щоб ставати самими собою, одержуючи радість від буттєвої повноти життя. 